\title{
Localization of the MARCKS (87 kDa) Protein, A Major Specific Substrate for Protein Kinase C, in Rat Brain
}

\author{
Charles C. Ouimet, James K.T. Wang, ${ }^{a}$ S. Ivar Walaas, ${ }^{b}$ Katherine A. Albert, and Paul Greengard \\ Laboratory of Molecular and Cellular Neuroscience, The Rockefeller University, New York, New York 10021
}

The localization of MARCKS (myristoylated, alanine-rich C-kinase substrate), a major specific substrate for protein kinase $\mathbf{C}$, has been studied in the rat brain. Light microscopic immunocytochemistry and biochemical analysis demonstrated that the protein is widespread throughout the brain and enriched in certain regions, including the piriform and entorhinal cortices, portions of the amygdaloid complex, the intralaminar thalamic nuclei, the hypothalamus, the nucleus of the solitary tract, nucleus ambiguus, and many catecholaminergic and serotonergic nuclei. Electron microscopic analysis revealed immunoreactivity in axons, axon terminals, small dendritic branches, and occasionally in dendritic spines. In neuronal processes, immunoreactivity was particularly prominent in association with microtubules, but reaction product was also seen in cytosol and adjacent to plasma membranes. No reaction product was observed in large dendrites, somata, or nuclei. A population of strongly immunoreactive glial cells was also observed. Many of these glial cells were morphologically similar to microglial cells, although some resembled astrocytes. In glial cells, both cytoplasm and plasma membranes were heavily labeled. The distribution of the MARCKS protein did not coincide precisely with the distribution of any of the subspecies of protein kinase $C$. The results indicate that the MARCKS protein is expressed in the majority of cell types in the CNS, and they suggest that the protein may be involved both in glial cell functions and in neuronal functions involving cytoskeletal elements in small dendritic branches and axon terminals.

Calcium/diacylglycerol-dependent protein kinase plays an important role in neuronal functions such as neurotransmitter release and ion channel activity and appears to be involved in certain types of neuronal plasticity such as long-term potentiation (Nishizuka, 1986; Kikkawa and Nishizuka, 1988; for review, see Kaczmarec, 1987). Distinct phosphoproteins are presumed to mediate the pleiotropic effects of protein kinase C. An elongated, acidic protein of $M_{r} 31,950$, which upon SDS-PAGE displays an apparent molecular mass of 80-87,000 Da, has been

\footnotetext{
Received Aug. 25, 1989; revised Nov. 29, 1989; accepted Nov. 30, 1989.

This work was supported by USPHS grant MH 39327 to P.G. and a grant from The Esther \& Joseph Klingenstein Fund to C.C.O. We thank Victoria Wells for her expert technical assistance.

Correspondence should be addressed to Dr. Charles C. Ouimet, Psychology Department, Florida State University, Tallahassee, FL 32306.

a Present address: Program in Neurosciences, Tufts University School of Medicine, Boston, MA 02111.

${ }^{\mathrm{b}}$ Present address: Institute of Biochemistry, University of Oslo, 0317 Oslo 3, Norway.

Copyright (c) 1990 Society for Neuroscience $0270-6474 / 90 / 051683-16 \$ 02.00 / 0$
}

identified as a major specific substrate for protein kinase $\mathrm{C}(\mathrm{Wu}$ et al., 1982; Rozengurt et al., 1983; Walaas et al., 1983a, b; Albert et al., 1986, 1987; Patel and Kligman, 1987). This myristoylated, alanine-rich C-kinase substrate (MARCKS) protein (Stumpo et al., 1989) is particularly enriched in brain but displays a widespread tissue distribution (Albert et al., 1986; Blackshear et al., 1986). Biochemical studies indicated that the protein is present in both membrane and cytosolic fractions (Walaas et al., 1983a, b; Albert et al., 1986, 1987; Patel and Kligman, 1987). In macrophages, a fraction of the protein is myristoylated

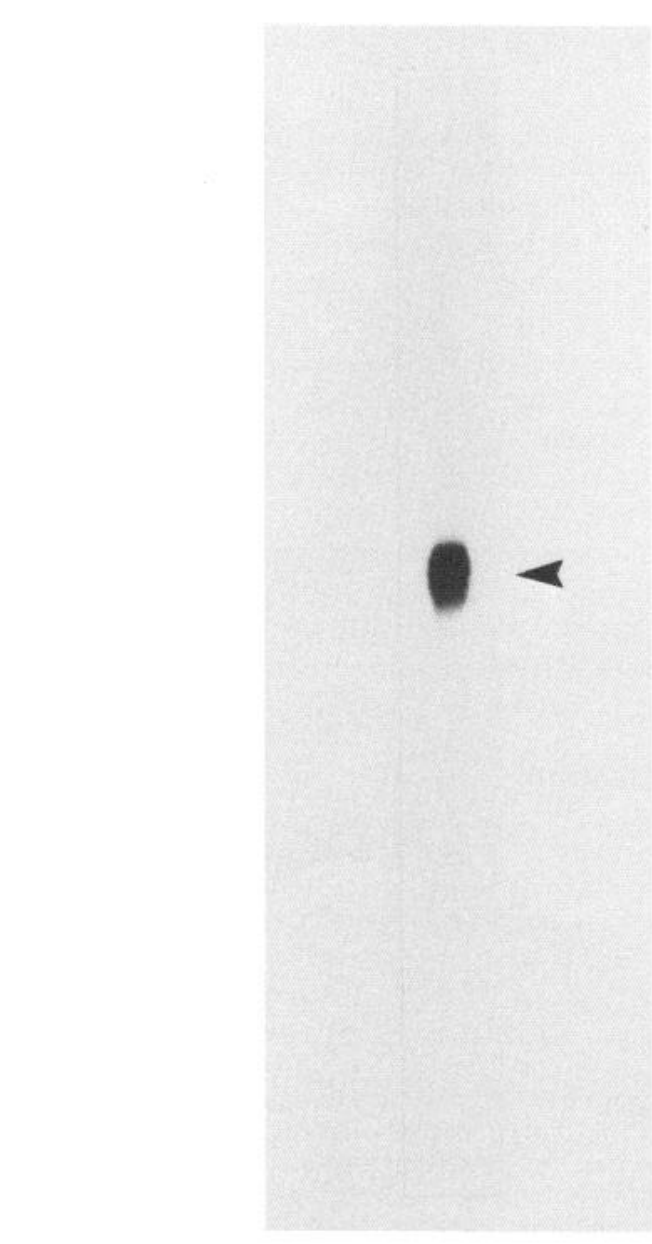

Figure 1. Immunoblot of rat brain homogenate with affinity-purified antibody. Antiserum against the MARCKS protein was affinity purified as described in Materials and Methods and was used to immunoblot a strip of rat brain cortical homogenate. Arrow indicates the MARCKS protein, which is the only immunoreactive band on the strip. 
Figure 2. Regional distribution of the MARCKS protein in rat brain. Rat brain regions were microdissected and homogenized, and equal aliquots were immunoblotted for the MARCKS protein as described in Materials and Methods. All values are normalized to the highest amount which was set at $100 \%$.

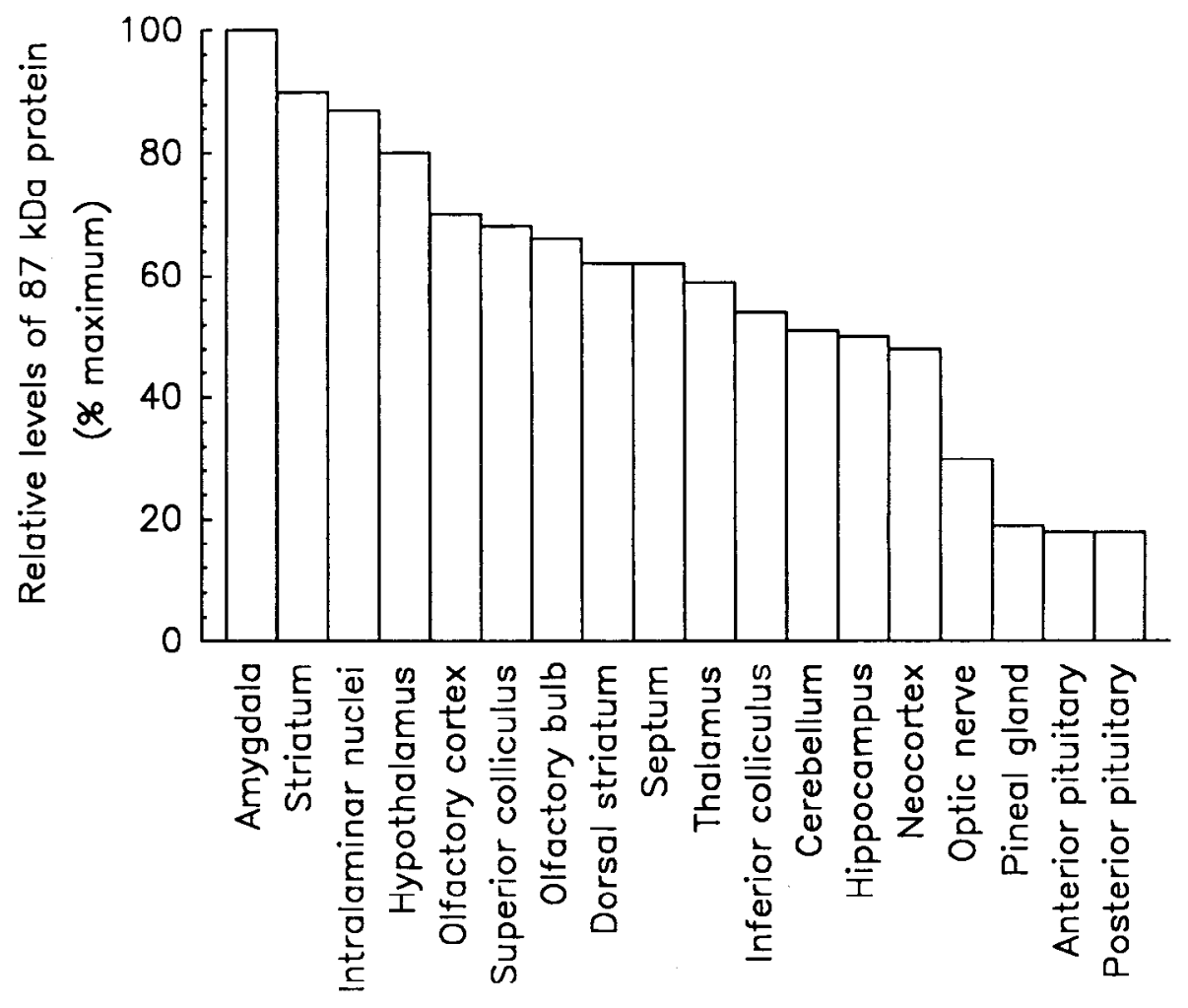

and is associated with membranes, while the phosphorylated form of the protein is found mainly in the cytosol (Aderem et al., 1988). In isolated nerve terminals, phosphorylation of the MARCKS protein by protein kinase $C$ leads to its translocation from membrane to cytosol (Wang et al., 1989). Due to a lack of knowledge of the exact cellular localization of the protein, the functional and structural importance of these changes has been difficult to ascertain.

The present study examines the regional and subcellular distribution of the MARCKS protein in rat brain by immunochemical and immunocytochemical methods. The data indicate that the protein is enriched in certain brain regions; it is most easily detected in axons, axon terminals, dendrites of small diameter, and dendritic spines. In addition, it is also present in distinct populations of glial cells.

\section{Materials and Methods}

Production and characterization of antibodies against the MARCKS protein. The MARCKS protein was purified from rat brain according to the method described for bovine brain (Albert et al., 1987). Antiserum against purified MARCKS protein was raised in a Ncw Zcaland rabbit as previously described (Albert et al., 1986). Affinity purification of the antiserum was performed essentially according to the protocol of Olmsted (1981). Briefly, $16 \mathrm{mg}$ of rat brain cortical homogenates were subjected to SDS-PAGE, followed by electrotransfer onto nitrocellulose membranes and immunoblotting with the specific antiserum diluted 2-fold (Albert et al., 1986). Antibodies bound to the MARCKS region of the blots were then eluted into a final volume of $5 \mathrm{ml}$ (Olmsted, 1981) and used for immunocytochemistry. Two-dimensional gel electrophoresis (Wang et al., 1988) showed that the antiserum did not crossreact with any proteins that comigrated with the MARCKS protein upon SDS-PAGE (unpublished obscrvations). The specificity of the affinitypurified antibody was confirmed by blots of brain homogenates in which only the MARCKS protein was recognized (Fig. 1).

Quantitative analysis of the MARCKS protein. Male Sprague-Dawley rats $(150-200 \mathrm{gm})$ were stunned, decapitated, and their brains were rapidly removed, cooled on ice, and dissected as described (Walaas et al., 1983a). In addition, the anterior and posterior pituitary gland, pincal gland, and intracranial part of the optic nerve (between the olfactory bulb and the optic chiasm) were dissected as well. The samples were frozen and kept in liquid $\mathrm{N}_{2}$. For analysis, the frozen samples were sonicated in $1 \%$ SDS and heated in a boiling water bath for $5 \mathrm{~min}$. Following determination of protein concentration (Smith et al., 1985), samples containing equal amounts of protein were subjected to SDSPAGE and immunoblotted for the MARCKS protein using ${ }^{125}$ I-protein A as described previously (Albert et al., 1986). To quantify the relative

Figure 3. Photomicrographs of MARCKS immunostaining in coronal sections through the rat brain at the following levels: $A$, forceps minor; $B$ and $C$, caudatoputamen; $D-G$, hypothalamus; $H$, midbrain. These photomicrographs are negative images produced by placing microscope slides in an enlarger to produce images on photographic paper. The brightest areas are regions that contain the strongest immunoreactivity. The gray areas are also immunoreactive, but to a lesser extent, and this immunoreactivity is better appreciated in high-power dark-field photomicrographs such as Figure 6. Immunoreactive regions contain labeled puncta and processes that are difficult to resolve at the light microscopic level. In addition, immunoreactive glial cells are present throughout the brain. Neuronal somata and major dendrites are not immunoreactive under the conditions employed. $A$, nucleus accumbens; $a c$, anterior commissure; $A m$, amygdaloid area; $B L$, basolateral amygdaloid nucleus; $C P$, caudatoputamen; $E n$, endopiriform nucleus; $E n t$, entorhinal cortex; fm, forceps minor; $H$, hippocampal formation; $H y$, hypothalamus; $M E$, median eminence; $M G N$, medial geniculate nucleus; $O P T$, olivary pretectal nucleus; $O T$, olfactory tubercle; $P G$, periaqueductal gray; $P i r$, piriform cortex; $R$, rhinal fissure; $S$, septum; $S C$, superior colliculus; $S N$, substantia nigra; $S T$, stria terminalis; VP, ventral pallidum; arrow, fundus striati; arrowheads, layer IV; asterisk, mammillary nuclei. Scale bar, $1 \mathrm{~mm}$. 
A

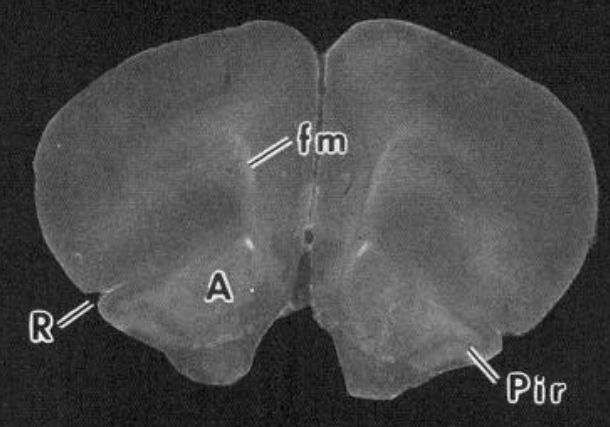

B

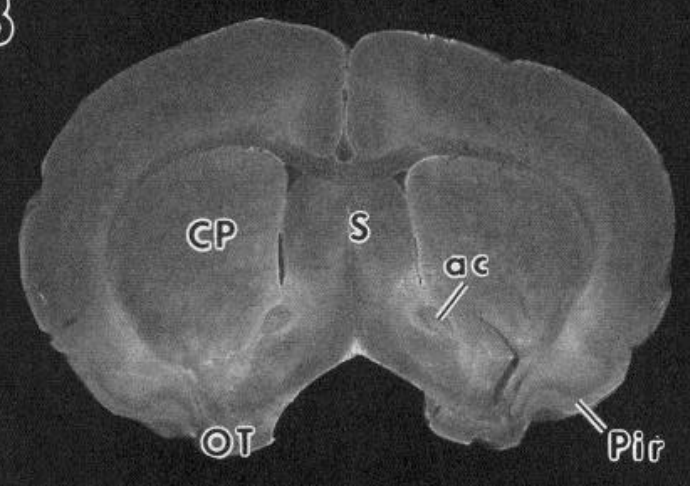

C

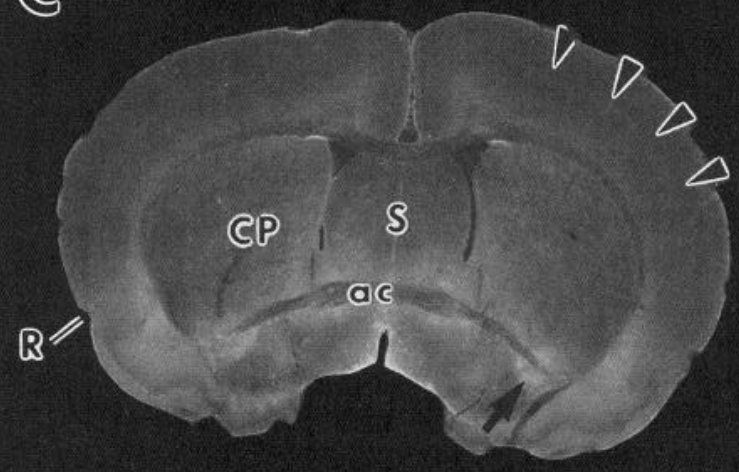

(D)

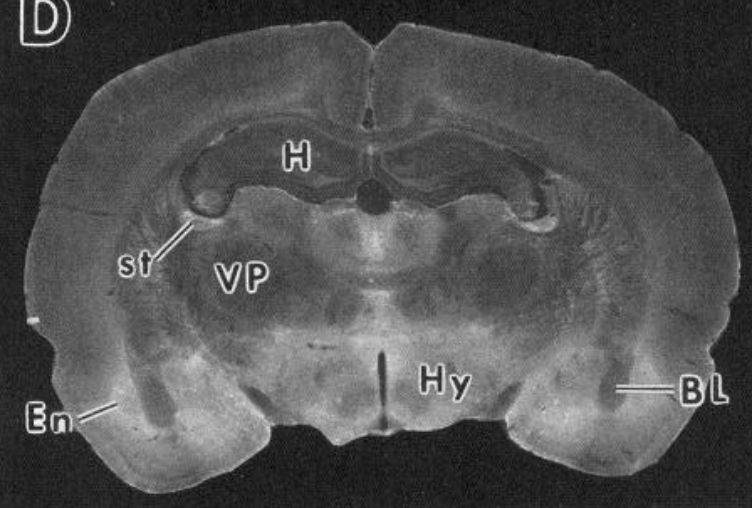

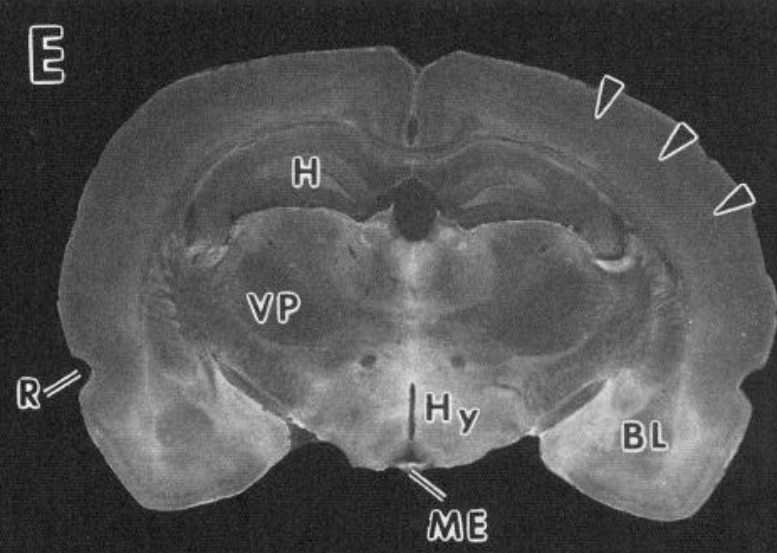

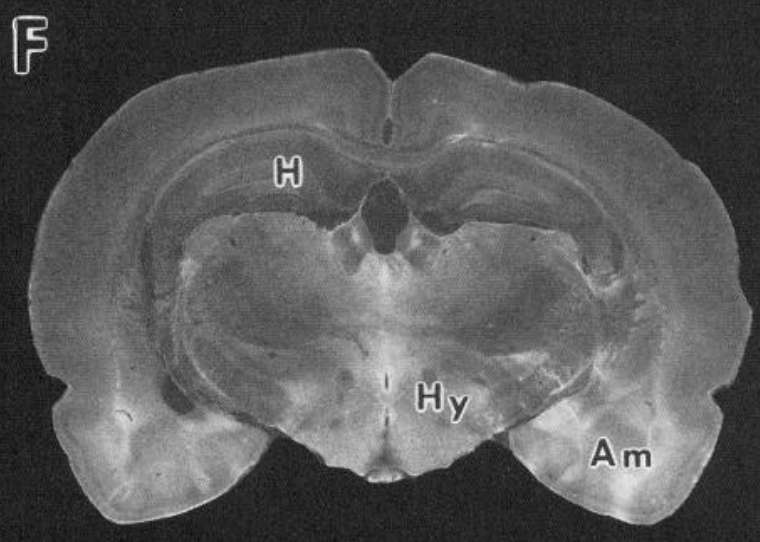

(G)

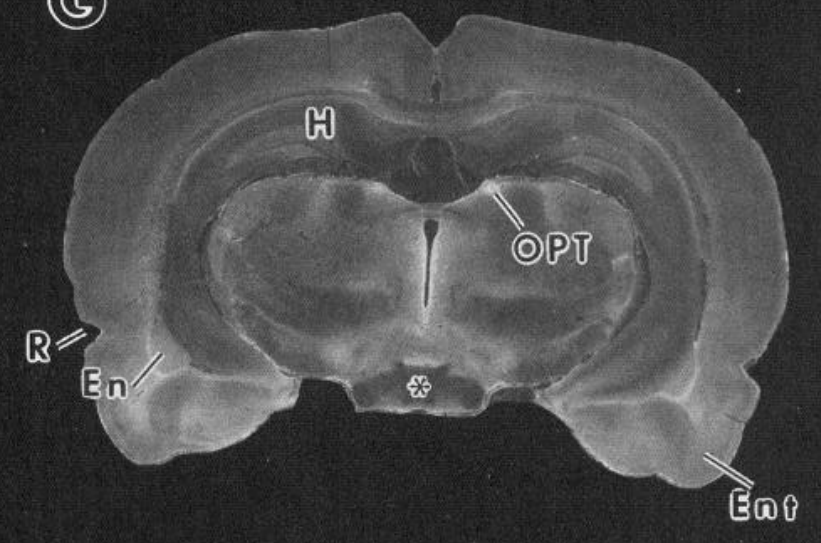

H

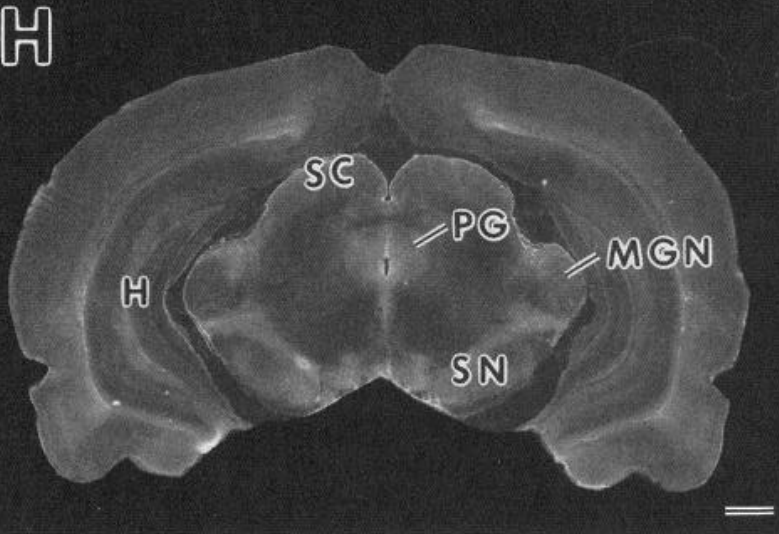




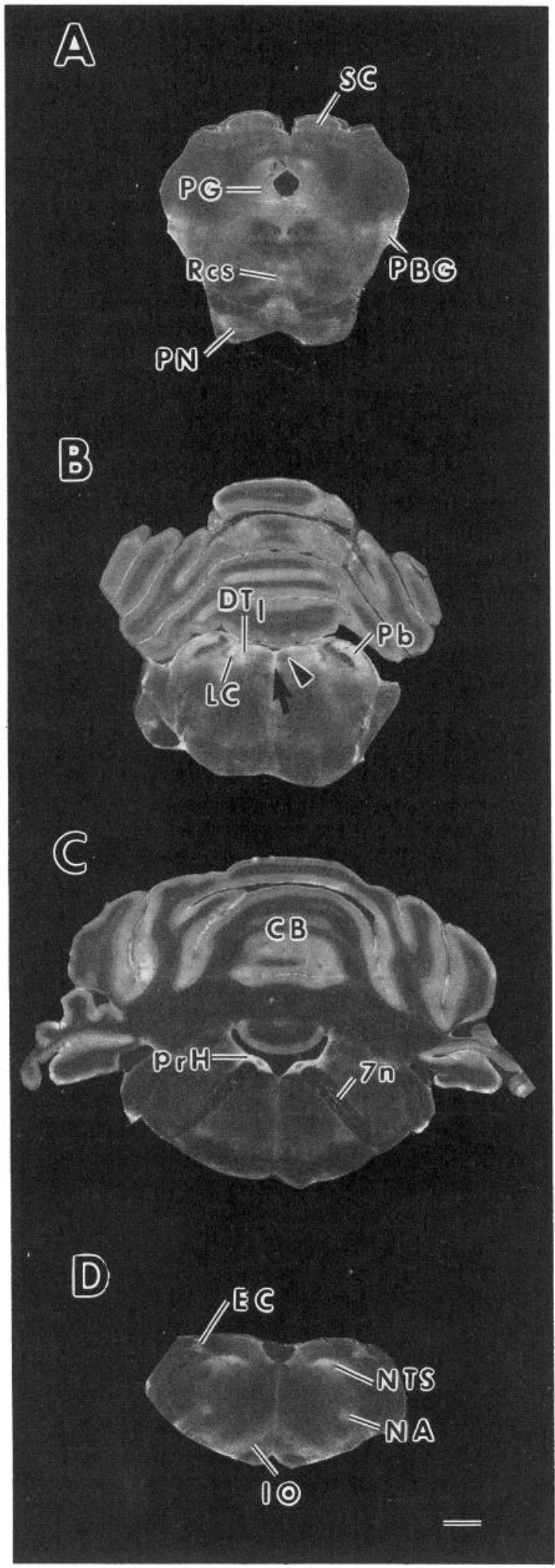

amounts of MARCKS protein in each sample, 2-200 $\mu \mathrm{g}$ of cortical synaptosomal protein were also immunoblotted to construct a "standard curve." This was used to convert the cpm value of each sample to a specific activity relative to the value in cerebral cortex synaptosomes. All data were then normalized to the highest value which was set at $100 \%$.

Immunocytochemical procedures. Male Sprague-Dawley rats (150 gm) were anesthetized with chloral hydrate $(350 \mathrm{mg} / \mathrm{kg}$ ) and perfused with a cannula placed through the heart into the aorta. Fixatives containing either $4 \%$ formaldehyde (freshly depolymerized from paraformaldehyde) or $2 \%$ formaldehyde and $1.25 \%$ glutaraldehyde in $10 \mathrm{~mm}$ sodium phosphate buffer ( $\mathrm{pH}$ 7.4) were found to give identical immunostaining patterns, but the mixture of formaldehyde and glutaraldehyde was chosen because it gave better morphological preservation at the electron microscopic level. For light microscopy, perfusion with $500 \mathrm{ml}$ fixative was preceded by perfusion with $150 \mathrm{ml}$ of $10 \mathrm{~mm}$ sodium phosphate buffer. This step was omitted for the electron microscopic studies.

Fixative was delivered at a pressure of $60 \mathrm{~mm} \mathrm{Hg}$ with a peristaltic pump. Brains were allowed to postfix for $1 \mathrm{hr}$ in situ and were then cut in the coronal plane into $3 \mathrm{~mm}$ slabs. The slabs were subsequently cut into $100 \mu \mathrm{m}$ sections on a vibratome and collected in PBS containing $10 \mathrm{~mm}$ sodium phosphate and $0.15 \mathrm{~m}$ sodium chloride ( $\mathrm{pH}$ 7.4). The sections were then immersed in sodium borohydride (1\% in PBS) for $30 \mathrm{~min}$, rinsed in PBS $(3 \times 15 \mathrm{~min})$, and incubated with the affinitypurified antibody to the MARCKS protein (described above) for $18 \mathrm{hr}$ at room temperature on a tissue shaker. Preliminary experiments, using dilutions of the antibody between $1: 10$ and $1: 10,000$ indicated that optimal immunostaining was achieved at a dilution of 1:25 (not shown). This dilution was used in subsequent studies.

Following incubation with primary antibody, the sections were washed in PBS $(3 \times 10 \mathrm{~min})$ and incubated with the following components from a Vector ABC Kit (Vector Laboratories) according to their instructions: biotinylated horse antirabbit $\mathrm{IgG}(1: 100)$ for $1 \mathrm{hr}$, followed by avidin-biotin-HRP complex for $1 \mathrm{hr}$. PBS washes $(3 \times 10 \mathrm{~min})$ were used between steps. The sections were immersed in $50 \mathrm{ml}$ of $0.1 \mathrm{M}$ sodium phosphate buffer containing $25 \mathrm{mg}$ 3,3-diaminobenzidine and $10 \mu \mathrm{l}$ of $30 \% \mathrm{H}_{2} \mathrm{O}_{2}$ for $2 \mathrm{~min}$. For light microscopy, sections were then mounted on subbed slides, coverslipped with Permount, and examined. For electron microscopy, sections were osmicated in $2 \%$ osmium tetroxide in $0.1 \mathrm{M}$ sodium phosphate buffer for $20 \mathrm{~min}$, dehydrated in a graded series of ethanol solutions, and embedded in EMBED-812 (Electron Microscopic Sciences). Sections $80 \mathrm{~nm}$ thick were cut on an ultratome and examined in a JEOL $100 \mathrm{cx}$ electron microscope without prior staining in either lead citrate or uranyl acetate.

The specificity of the staining protocol was assessed by the substitution of the following for the primary antibody: (1) diluent without primary antibody, (2) normal rabbit serum, (3) serum antibodies directed against irrelevant antigens. None of these substitutions produced immunostaining similar to that of the primary antibody to the MARCKS protein. In addition, omission of the secondary antibody or of the avidin-biotinHRP complex led to a total lack of staining (not shown). Potential

Figure 4. Photomicrographs of immunostaining for the MARCKS protein in coronal sections through the rat brain at the following levels: $A$, pontine nuclei; $B$, locus coeruleus; $C$, seventh cranial nerve; and $D$, nucleus tractus solitarius. These photomicrographs were prepared as for Figure 3. $C B$, cerebellum; $D T 1$, dorsal tegmental nucleus, pars lateralis; $E C$, external cuneate nucleus; $I O$, inferior olive; $L C$, locus coeruleus; $N A$, nucleus ambiguus; $N T S$, nucleus of the solitary tract; $P B$, parabrachial nucleus (dorsal portion); $P B G$, parabigeminal nucleus; $P G$, periaqueductal gray; $P N$, pontine nuclei; $P r H$, prepositus hypoglossal nucleus; $R c s$, centralis superior raphe nucleus; $S C$, superior colliculus; $7 n$, seventh cranial nerve; arrow, dorsal raphe nucleus; arrowhead, paracentral dorsal tegmental nucleus. Scale bar, $1 \mathrm{~mm}$.

Figure 5. Photomicrographs of glial cells (arrowheads) immunoreactive for the MARCKS protein in frontal cortex $(A)$, cingulate cortex $(B)$, and hypothalamus $(C, D)$. In $A$ and $C$, the glial cells are partially wrapped around neuronal cell bodies (arrows) that are not immunoreactive. Note that the punctate immunostaining is greater in the hypothalamus $(C, D)$ than in the cortical regions and that the processes containing the immunoreactivity are difficult to resolve. Scale bar, $10 \mu \mathrm{m}$. 

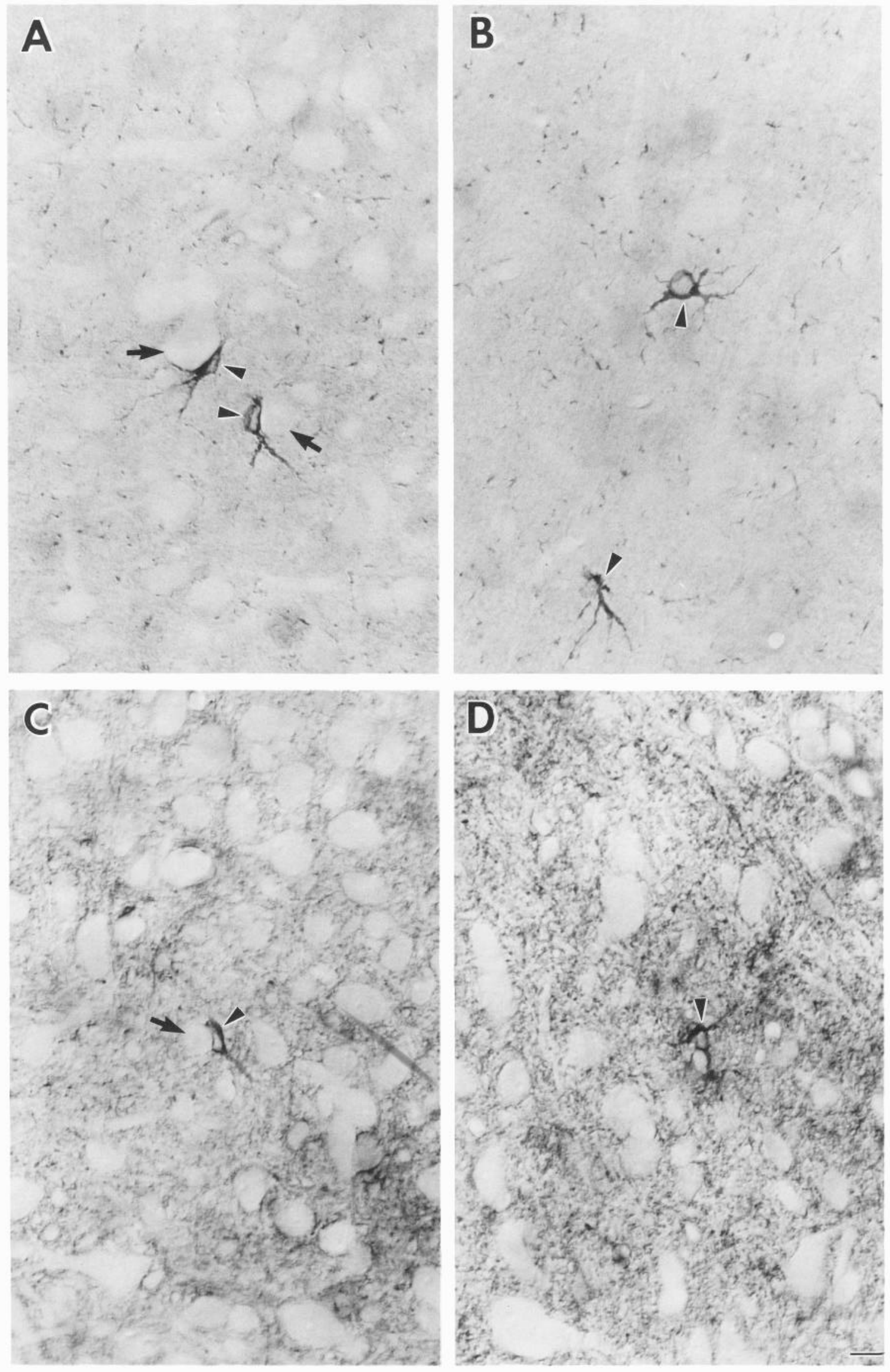
Figure 6. Dark-field photomicrograph of immunoreactivity for the MARCKS protein in neocortex (area 18). Immunoreactivity, which appears white, is stronger in layer IV than in other cortical layers. Immunoreactivity is also strong in layer I. This staining pattern is difficult to visualize without dark-field optics but can also be faintly seen throughout cortex in Figure 3. IVI signify the layers of neocortex as determined in a Nissl-stained adjacent section. Scale bar, $100 \mu \mathrm{m}$.

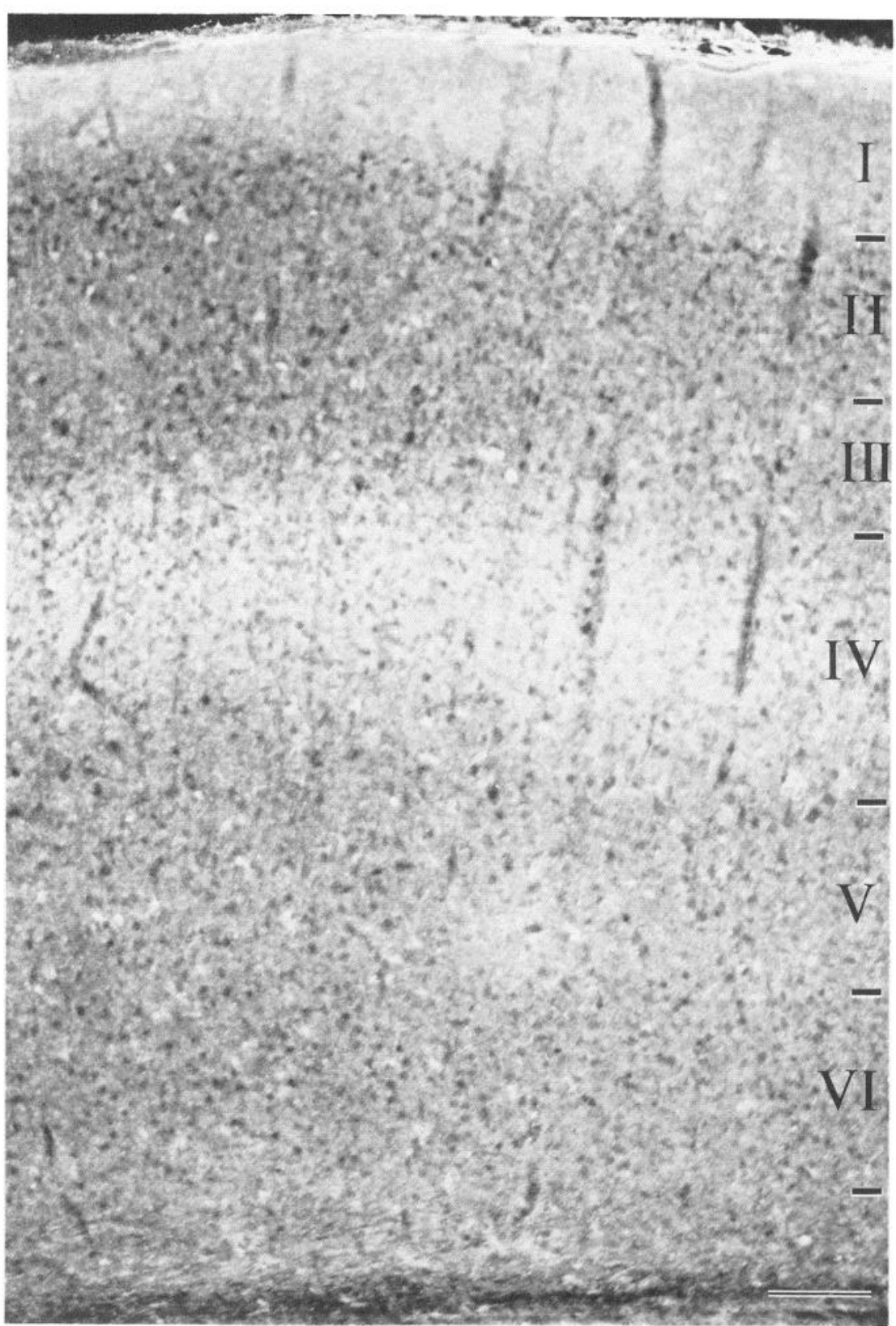

contamination of the primary antibody with antibodies against other antigens was avoided by affinity purification of the primary antibody as described above.

All light microscopic photomicrographs were taken with bright-field optics except for Figures 3, 4, 6, and 9C.

\section{Results}

\section{Immunoblotting}

Immunoblotting analysis of the MARCKS protein in microdissected brain regions showed that the protein was widely but not homogeneously distributed (Fig. 2). The highest levels of the MARCKS protein were found in the amygdala, ventral striatum, intralaminar thalamic nuclei, and hypothalamus. The lowest levels were found in the optic nerve and the pituitary and pineal glands (Fig. 2). The brain stem and spinal cord also contained low levels of the protein (data not shown).

\section{Light microscopy}

The distribution of the MARCKS protein observed by immunoblotting was consistent with that observed by light micro- scopic immunocytochemistry. Processes immunoreactive for the MARCKS protein were present throughout the brain, and immunostaining was more intense in some regions than in others (Figs. 3, 4). Most of the immunoreactivity was confined to small structures that appeared somewhat punctate but could not be further resolved at the light microscopic level (Figs. 5-10). In addition, a population of cells having small soma diameters (5$8 \mu \mathrm{m}$ ) and scant cytoplasm were immunoreactive (Fig. 5). These small cells were morphologically similar to microglial cells, although some resembled astrocytes.

The strongest immunostaining was present in the piriform and entorhinal cortices, portions of the amygdaloid complex, portions of the ventral striatum, the intralaminar nuclei of the dorsal thalamus, nucleus reuniens, hypothalamus, portions of the medial geniculate nucleus, substantia nigra pars compacta, ventral tegmental area, parabigeminal nucleus, parabrachial nucleus, periaqueductal gray region, molecular layer of the cerebellum, locus coeruleus, raphe nuclei, nucleus of the solitary tract, nucleus ambiguus, external cuneate nucleus, nucleus pre- 
The Journal of Neuroscience, May 1990, 10(5) 1689
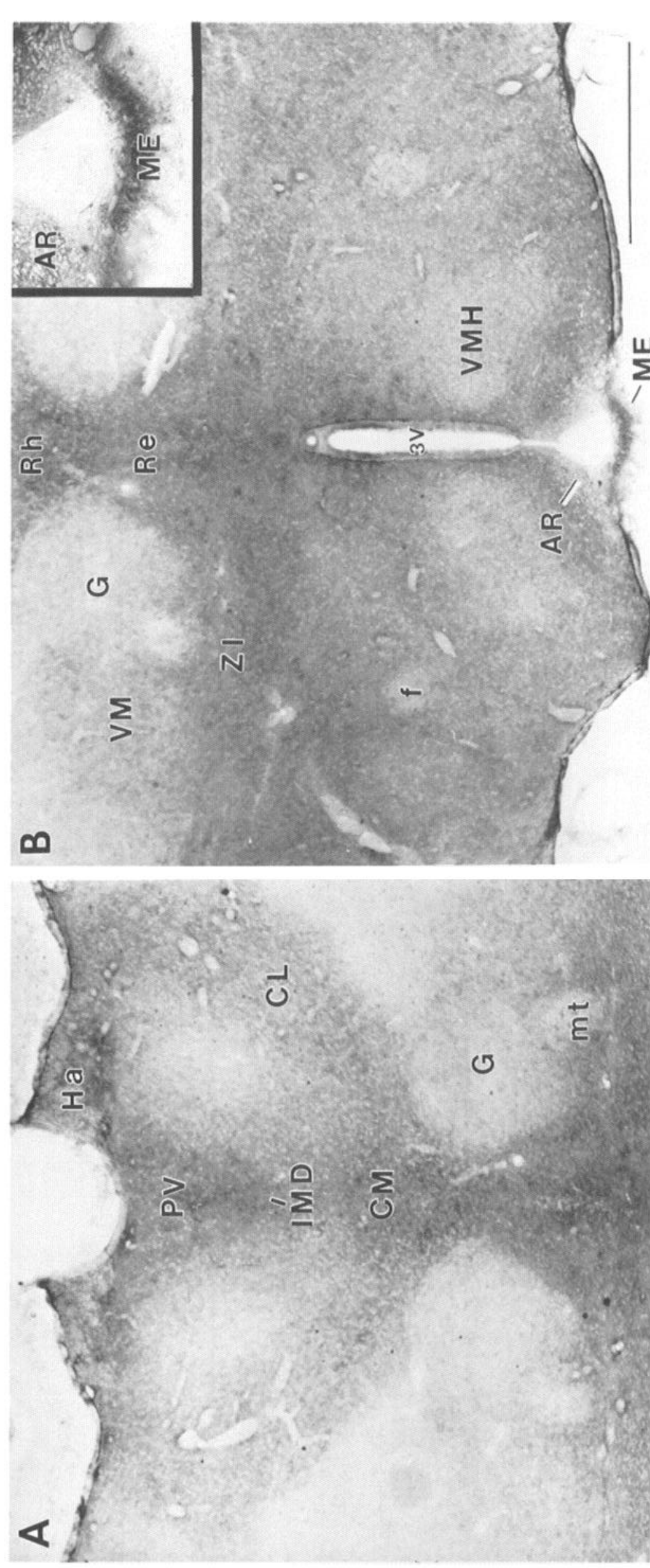

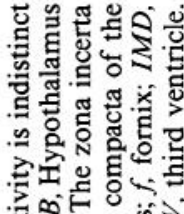

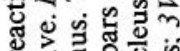

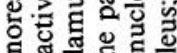

药

글

들웡

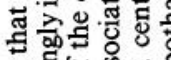

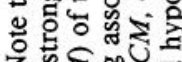
z

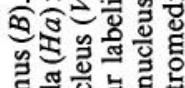

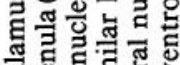

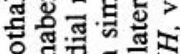

응동

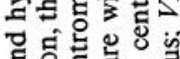

政行行

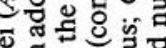

的设

욜 ह

章 중

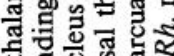

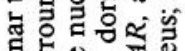

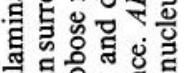

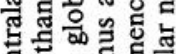

品远

记

a 동 영

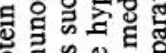
을

.

记

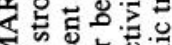

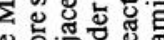

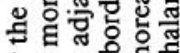

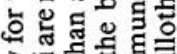
웡

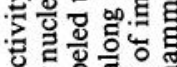
ब류

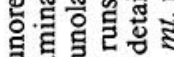

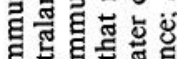
트를의 唡

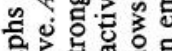

. of 实

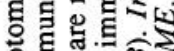
형

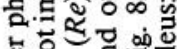

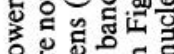

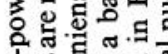
政

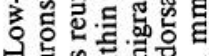
.

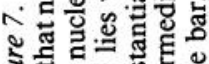

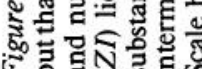




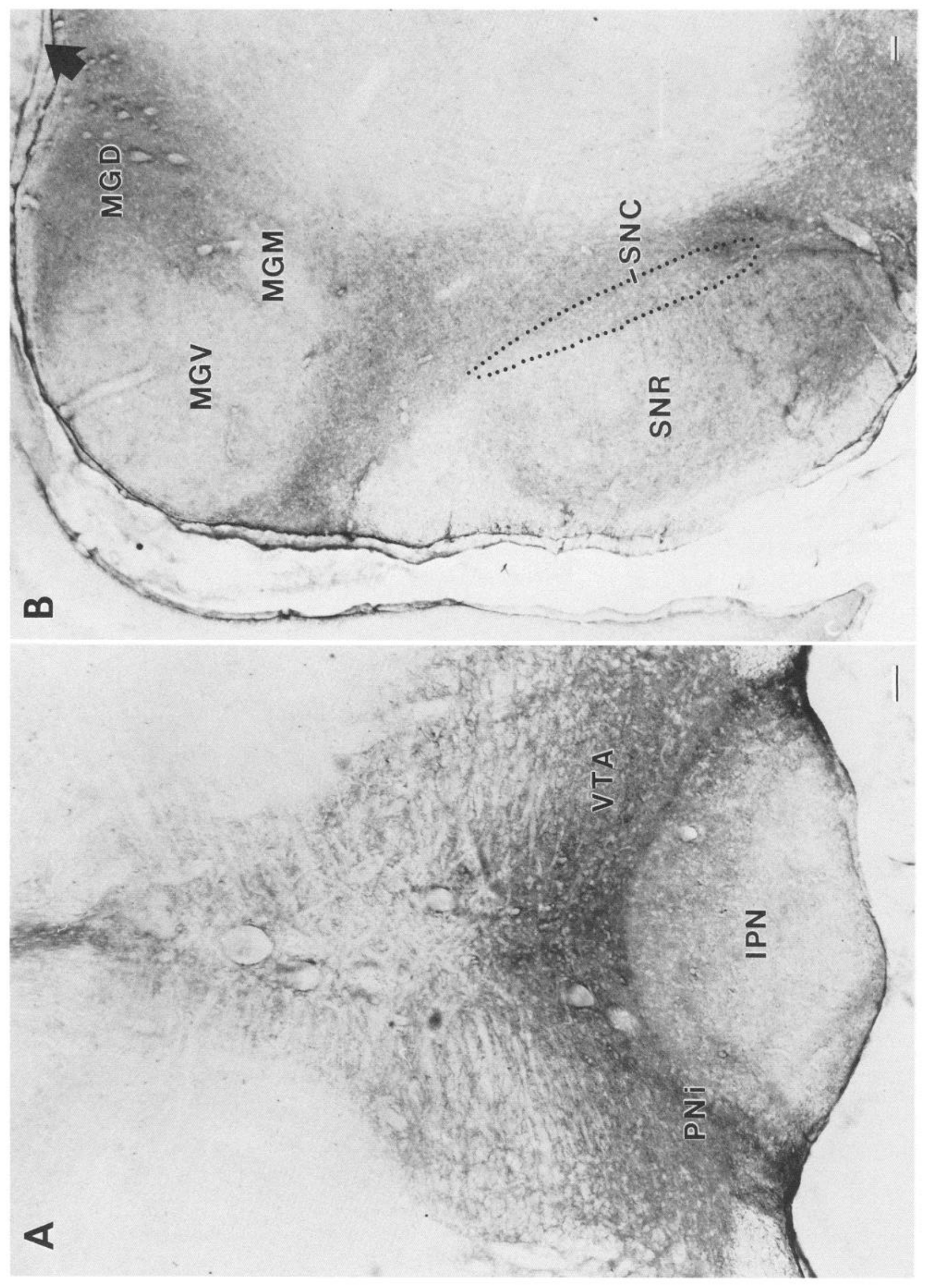



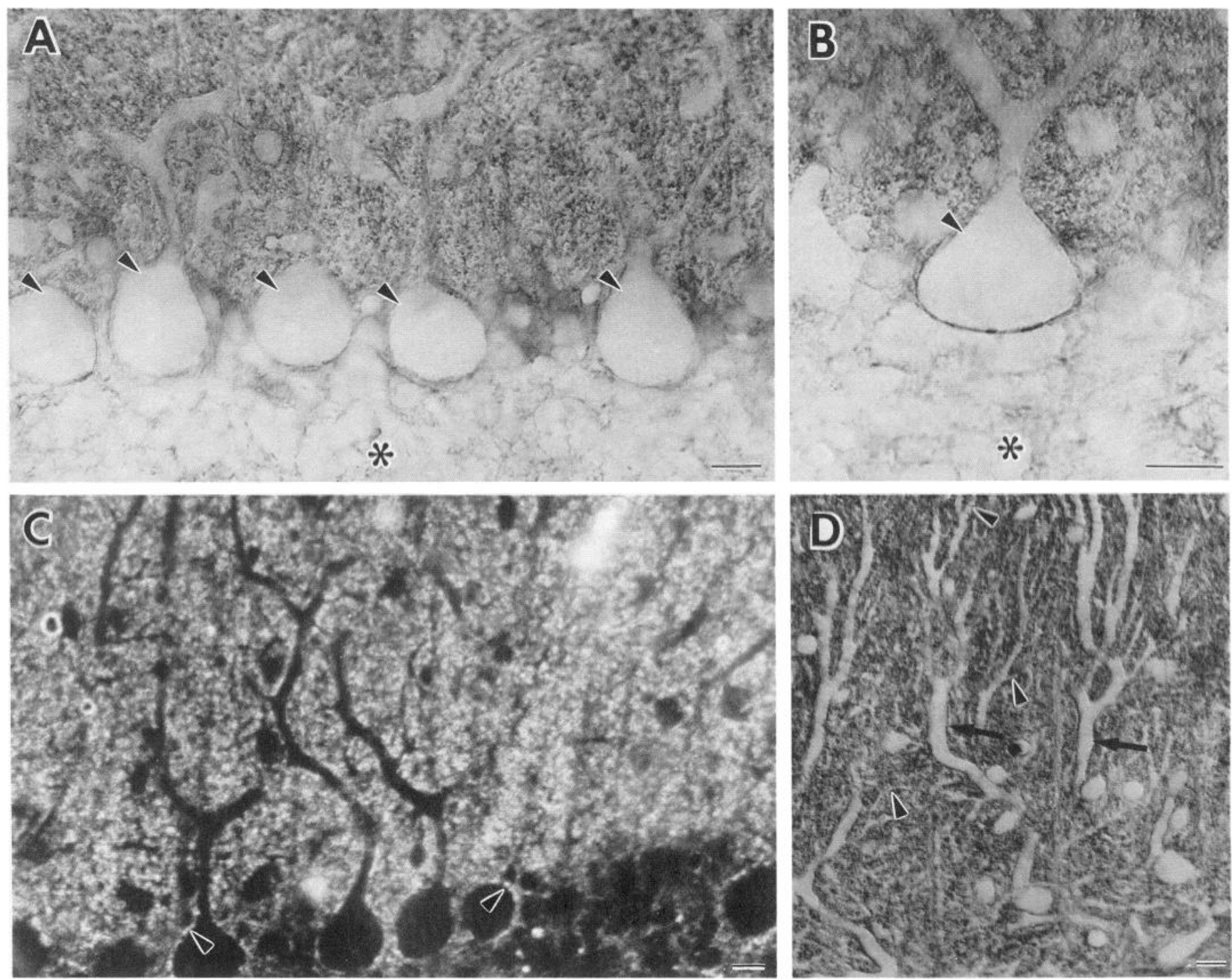

Figure 9. Photomicrographs of MARCKS protein immunolabeling in the cerebellum. Immunoreactivity is stronger in the molecular layer than in the granule cell layer (asterisks in $A$ and $B$ ) and has a punctate appearance. $A$, Purkinje cells. Purkinje cell bodies (arrowheads) are not immunoreactive under the conditions employed in these experiments. $B$, A Purkinje cell body surrounded by immunoreactive material. $C$, Appearance of immunoreactivity in a dark-field photomicrograph of the cerebellum. Purkinje cells and their dendrites are not immunoreactive. Purkinje cell somata are surrounded by immunoreactive puncta (arrowheads) about $1 \mu \mathrm{m}$ in diameter. $D$, Lack of immunoreactivity in large (arrows) and small (arrowheads) branches of Purkinje cell dendrites near the pial surface. Scale bars, $10 \mu \mathrm{m}$.

positus hypoglossus, inferior olive (Figs. 3, 4) and Rexed laminae I, II, and $\mathrm{X}$ of the spinal cord (not shown). Weaker immunostaining was present in the remainder of the brain, but layers I and IV of the cerebral cortex showed an enhancement in immunostaining compared with the remaining layers (Figs. $3, C, E ; 6)$.

In the piriform and entorhinal cortices (Fig. 3, $A-H$ ) immunoreactivity was present in both the polymorph and molec- ular layers. Staining was less dense in the pyramidal layer because neuronal somata were unstained. In the amygdaloid complex, immunoreactivity was conspicuously weak or absent from the basolateral nuclei but strong in the remaining areas (Fig. 3, $D-F$ ). In the dorsal thalamus, the intralaminar nuclei, especially the centrolateral, centromedial, intermediodorsal, rhomboid, and paraventricular nuclei, were very strongly immunoreactive (Figs. 3, D-E; 7). At caudal levels, however, the

Figure 8. Low-power photomicrographs of immunoreactivity of the MARCKS protein in the midbrain. $A$, Immunoreactivity in the region of the ventral tegmental area $(V T A)$. Immunoreactivity is stronger in the ventral tegmental area and in the paranigral (PNi) area than in surrounding regions. Immunoreactivity is also present to a lesser extent in the interpeduncular nucleus $(I P N)$. $B$, Immunoreactivity associated with the substantia nigra and medial geniculate nucleus. The substantia nigra pars compacta $(S N C)$ lies within a band of immunoreactivity that extends from the VTA dorsolaterally to the outer portions of the medial geniculate nucleus. The dorsal $(M G D)$ and medial $(M G M)$ subdivisions of the medial geniculate nucleus are more immunoreactive than the ventral subdivision $(M G V)$. (Compare these photomicrographs with the lower-power photomicrograph in Fig. $3 H$ ). SNR, substantia nigra pars reticulata; closed arrow, dorsal surface of brain. Scale bars, $100 \mu \mathrm{m}$. 
Figure 10. Photomicrograph of immunoreactivity for the MARCKS protein in the hilus fasciae dentatae $(\mathrm{Hi})$ of the hippocampus. Immunoreactivity is stronger in the hilus than in the dentate gyrus (above and below the hilus in this photomicrograph). The granule cells (Gr) are notably nonimmunoreactive, while many immunoreactive glial cells are present in both the hilus and the dentate gyrus (arrowheads). Scale bar, $100 \mu \mathrm{m}$.

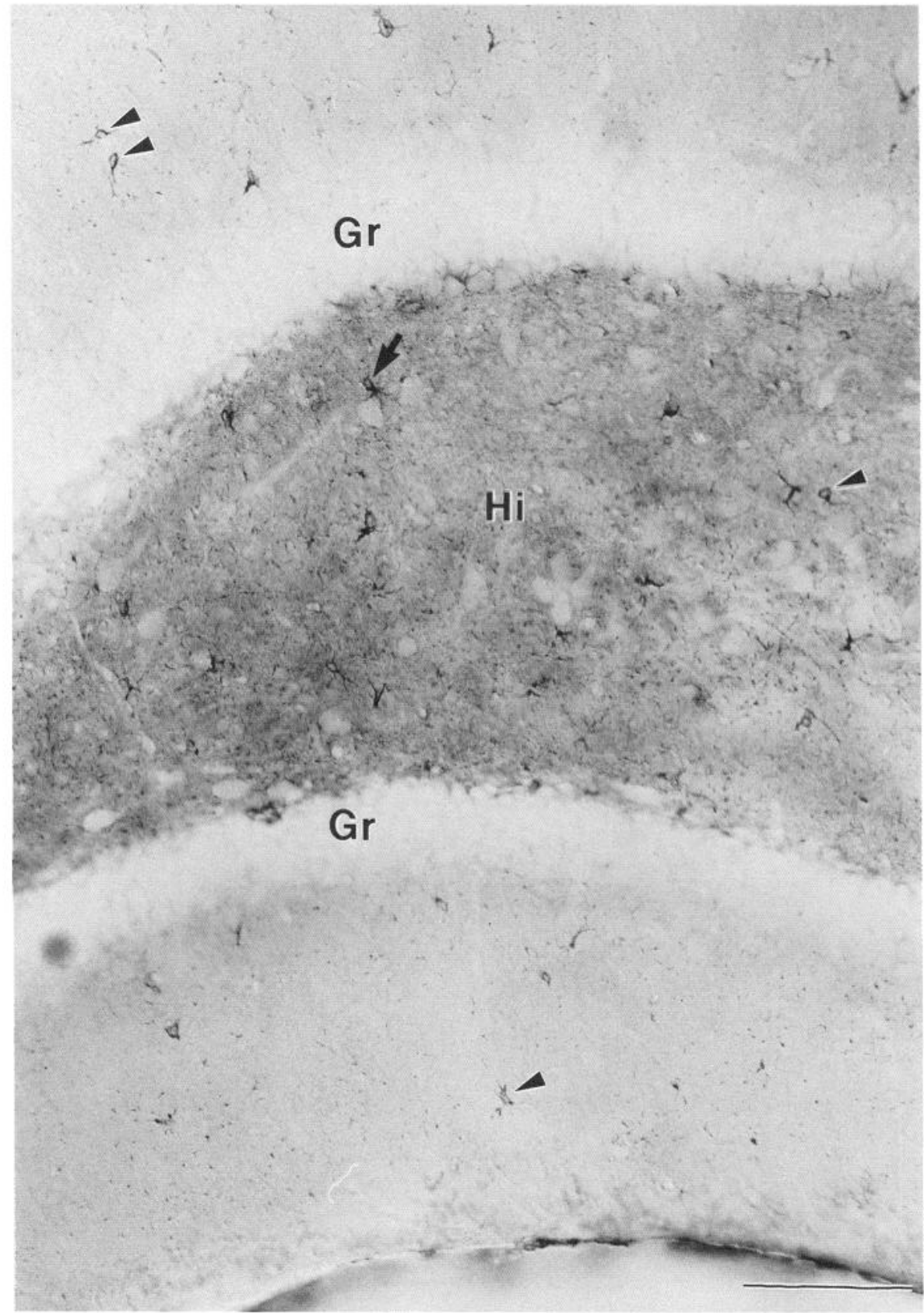

staining in the centrolateral nucleus was greatly reduced. Immunostaining was also very intense in the nucleus reuniens.

Strong immunoreactivity was present throughout the hypothalamus (Figs. $3, D-G ; 5 D ; 7 B$ ). The ventromedial and arcuate nuclei, however, were less immunoreactive than neighboring hypothalamic regions. A band of very heavy immunoreactivity was present in the inner third of the median eminence (Fig. 7).

In the midbrain, broad bands of strong immunoreactivity were associated with the medial geniculate nucleus, the interpeduncular nucleus, and the substantia nigra (Fig. 8). The substantia nigra pars compacta, medial and dorsal portions of the medial geniculate nucleus, paranigral nucleus, peripeduncular nucleus, and ventral tegmental area were included in the areas covered by these immunoreactive bands, which crossed borders rather than following the limits of specific nuclei (see, for example, the substantia nigra pars compacta in Fig. $8 B$ ).
Strong immunoreactivity in the cerebellum was confined to the molecular layer (Figs. 4, $B, C$; 9). Purkinje cell somata were unstained as were their primary and secondary dendrites, which could be followed through much of the molecular layer.

Immunostaining was not prominent in the hippocampal formation. Of the various hippocampal regions, the strongest immunostaining was present in the hilus (Figs. $3, D-H ; 10$ ). The cell bodies of granule cells were noticeably not immunoreactive. In contrast, numerous glial cells were strongly immunoreactive.

\section{Electron microscopy}

Three regions were examined at the ultrastructural level: the hypothalamus, the cingulate cortex, and the hippocampus (CA1). Immunostaining was similar in all 3 areas. In neurons, immunoreactivity was found in axons, axon terminals, small dendritic branches (0.5-0.8 $\mu \mathrm{m}$ diameter), and occasionally in den- 

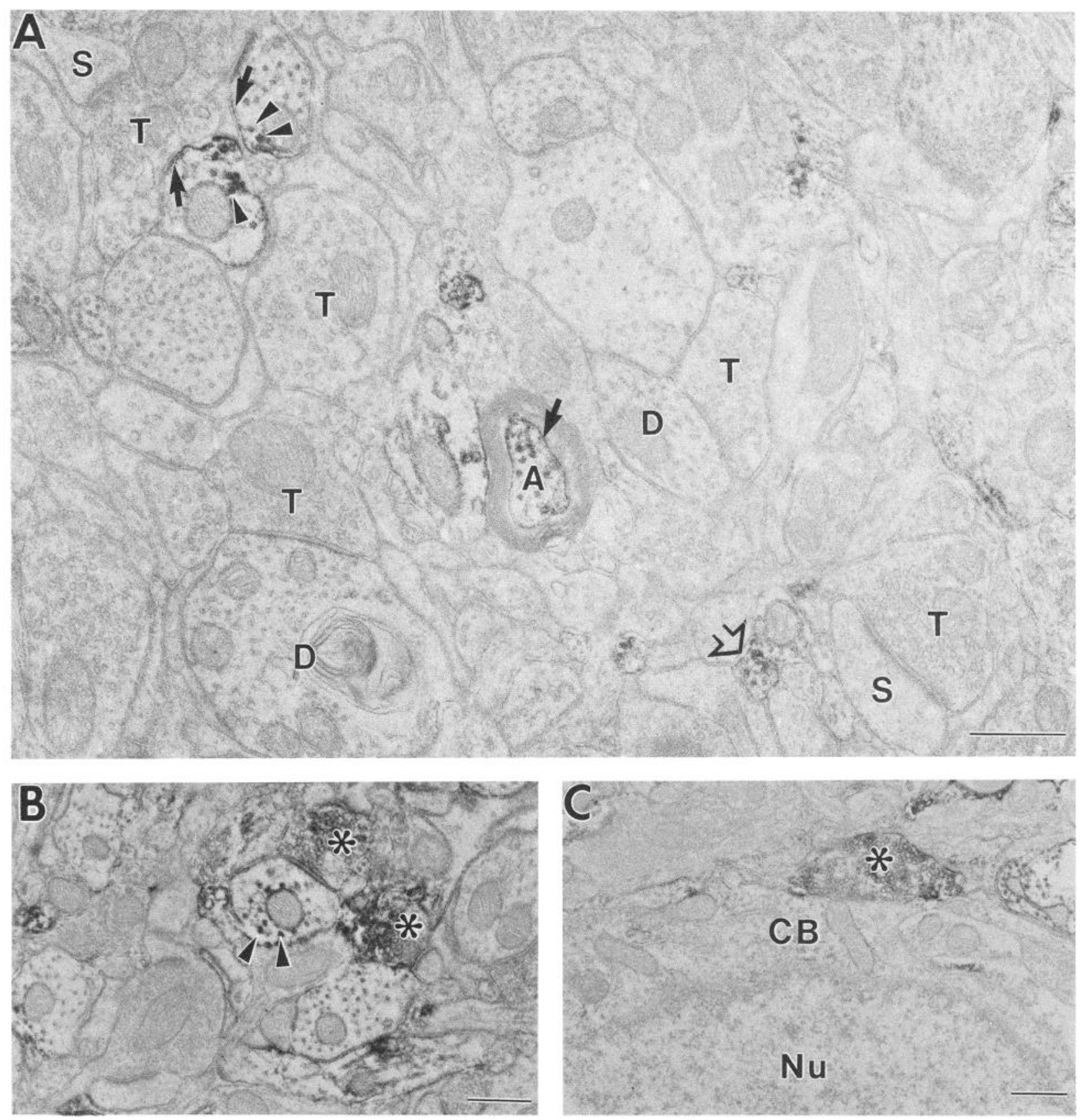

Figure 11. Electron micrograph of elements immunoreactive for the MARCKS protein. A, Immunoreactivity in dendrites and axons in cingulate cortex. Arrowheads point to immunoreactivity associated with dendritic microtubules in lightly stained material. Some immunoreactivity is also associated with the inner surface of plasma membranes in both dendrites and axons (see arrows, for examples). Immunoreactivity is present in a myelinated axon $(A)$ and in an unmyelinated axon (open arrow). Most of the spines, dendrites, and axon terminals in this field are not immunolabeled. $B$, Immunoreactivity in dendrites and axon terminals in cingulate cortex. Arrowheads point to immunoreactivity associated with microtubules, and asterisks identify immunoreactive axon terminals. $C$, Immunoreactivity in an axon terminal (asterisk) adjacent to a nonimmunoreactive neuronal cell body $(C B)$. Nu, an unlabeled nucleus; $D$, examples of unlabeled dendrites; $T$, examples of unlabeled axon terminals; $S$, examples of unlabeled spines. Scale bars, $0.5 \mu \mathrm{m}$.

dritic spines (Figs. 11-14). Neuronal somata, nuclei, and large dendrites ( $>0.8 \mu \mathrm{m}$ in diameter) were not immunoreactive under the conditions employed. Microtubules were especially heavily immunolabeled, and this staining was seen even in processes that otherwise were only lightly immunoreactive (see, for example, Figs. $11, A, B ; 13, A, B$ ). In addition, heavy immunoreactivity was often associated with the cytoplasmic surface of plasma membranes (Figs. 11 $A, 13 A$ ). No special accumula- tion of immunoreaction product was noted on postsynaptic densities.

Immunoreactivity was found in glial cell bodies and processes (Figs. 5, 10, 14). Immunolabeled glial cells had scant cytoplasm and elongate nuclei with coarse clumped chromatin (Fig. 14). Intensely immunoreactive glial processes were an especially prominent feature of immunostaining in the hypothalamus. Much of the immunoreaction product in glial processes was 
Figure 12. Electron micrograph of a spine (arrowhead) immunolabeled for the MARCKS protein in cingulate cortex. Two unlabeled spines $(S)$ are also present. Scale bar, $0.5 \mu \mathrm{m}$.

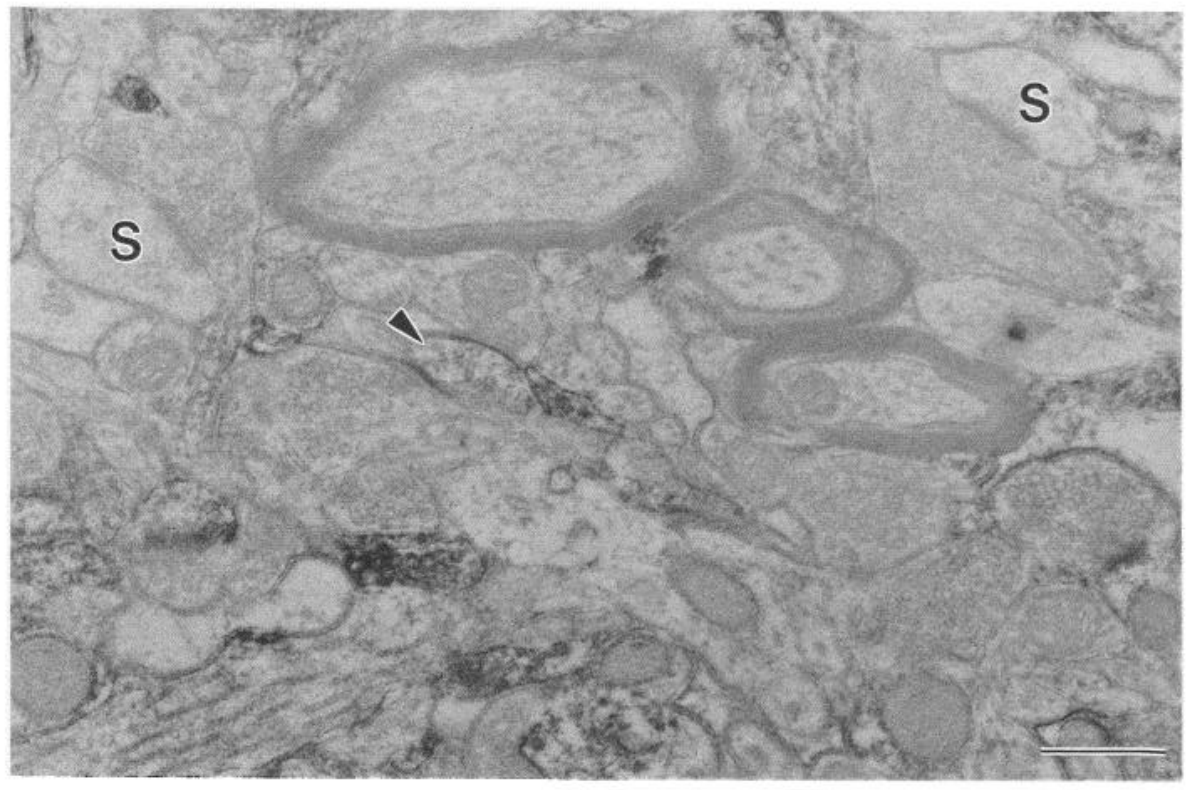

present on the cytoplasmic surface of the plasma membrane (Fig. 15, $A, C$ ). Immunoreactive glial processes enveloping preand postsynaptic elements (Fig. 15) or neuronal somata were also observed. In some instances, the glial membrane of these thin processes was entirely preserved (Fig. 14, inset). In other instances, limiting membranes were difficult to resolve (see, for example, Fig. 15).

\section{Discussion}

The present paper demonstrates that the MARCKS protein, a major specific substrate for protein kinase $C$, is widespread throughout the brain and enriched in certain areas. The regional distribution of the protein observed by immunocytochemistry is consistent with that observed by quantitative immunoblot analysis. Many of the regions that are enriched for the MARCKS protein, such as the piriform and entorhinal cortices, most of the amygdaloid complex, the parabrachial nucleus, and the hypothalamus, are either part of the limbic system or are associated with the limbic system. In addition, the MARCKS protein is enriched in nuclei that project diffusely upon other regions and that may play a role in general modulation of target areas. These regions include the intralaminar nuclei, parts of the locus coeruleus, zona incerta, substantia nigra, ventral tegmental area, raphe nuclei, and much of the medial (magnocellular) subdivision of the medial geniculate nucleus.

At the ultrastructural level, immunoreactivity for the MARCKS protein is associated with microtubules in dendrites and axons, and with the plasma membrane in dendrites, axons and glial processes. Within nerve cells, immunoreactivity for the MARCKS protein shows a restricted distribution. Immunoreactivity is absent from large dendrites and from neuronal somata, but is present in small dendrites, axons and axon terminals. Few immunolabeled spines were detected, presumably reflecting that most of the MARCKS protein immunoreactivity is associated with microtubules, which are absent from dendritic spines.

The microtubule-associated immunoreactivity is particularly apparent in preparations that are minimally stained; in such cases, the immunoreactivity present in a neuritic profile is essentially confined to the microtubules (mitochondria and postsynaptic densities, for example, were not usually labeled). Although immunolabeling with the HRP technique is difficult to interpret at the electron microscope level because the immunoreaction product can diffuse to nearby surfaces, where it can be fixed in place by osmication, these data are suggestive of an association of the MARCKS protein with microtubules and a role for the protein in the organization of the cytoskeleton. The association of immunoreactivity with the plasma membrane in small dendrites, axons, and glial processes may represent the fraction of the MARCKS that is membrane bound. This fraction of the protein is likely to be myristoylated and could be translocated upon phosphorylation by protein kinase $\mathrm{C}$ (Wang et al., 1989).

The MARCKS protein is enriched in higher-order dendritic branches of many or most neurons in immunoreactive regions. Thus, one role of the phosphoprotein may be related to functions specific to the higher-order branches of the dendritic tree. The axon terminal localizaton of the MARCKS protein is in agreement with the demonstration that the protein is present in synaptosomal fractions and growth cones (Katz et al., 1985; Dunkley et al., 1986; Hymand and Pfenninger, 1987; Wang et al., 1988). In axon terminals, immunoreactivity is associated with synaptic vesicles. Because the vesicles are tightly packed and fill most of the volume of the terminal, it is not possible at present to determine whether there is a preferential association of immunoreactivity with vesicle membranes.

High levels of the MARCKS protein are present in glial cells that resemble microglial cells and astrocytes, which may be difficult to distinguish on morphological criteria alone (Miles and Chou, 1988). Many glial cells that were immunoreactive for the MARCKS protein were clearly satellites of neurons (see, for example, Figs. 5, A, $C ; 10 ; 14)$, a characteristic feature of microglial cells (Rio-Hortega, 1932; Cammermeyer, 1970). In addition, most of the immunoreactive glial cells encountered at the electron microscopic level contained rod-shaped nuclei, clumped chromatin and scant cytoplasm, also characteristic of 
the microglial cell type (Rio-Hortega, 1932; Cammermeyer, 1970). The MARCKS protein is also present in macrophages (Aderem et al., 1988), a cell type closely related to microglia (for review, see Miles and Chou, 1988), but its function in these cells is unknown.

Immunoreactive glial cell processes were densest in the hypothalamus, where they contributed very significantly to the overall level of immunostaining. Such glial cell processes immunoreactive for the MARCKS protein frequently enveloped pre- and postsynaptic elements, indicating that they may be able to modify the proximity of pre- and postsynaptic elements to each other. A similar role for glial cell intervention between axon endings and blood vessels has already been suggested for tanycytes in the hypothalamus (Lichtensteiger and Richards, 1975; Meister et al., 1988), and for pituicytes and secretory endings in the posterior pituitary gland (Tweedle and Hatton, 1987).

It is of interest to compare the regional distribution of the MARCKS protein, a specific substrate for protein kinase $C$, with that of its phosphorylating enzyme. Protein kinase $\mathrm{C}$ appears to comprise several subspecies (Coussens et al., 1986; Knopf et al., 1986; Makowske et al., 1986; Ono et al., 1986a, b; Parker et al., 1986; Housey et al., 1987; Kubo et al., 1987; Ohno et al., 1987; Nishizuka, 1988), making the analysis of the localization of this enzyme complicated. Nonetheless, protein kinase $\mathrm{C}$ has been localized in rat brain by biochemical analysis of microdissected brain regions (e.g., Huang et al., 1987; Nelson et al., 1987; Walaas et al., 1983a, b), by autoradiographic analysis of phorbol ester binding (Worley et al., 1986) and by immunocytochemistry (Girard et al., 1985, 1988; Wood et al., 1986; Kitano et al., 1987; Mochly-Rosen et al., 1987; Ase et al., 1988; Hashimoto et al., 1988; Huang et al., 1988; Saito et al., 1988). The distribution of the MARCKS protein does not match exactly that of any of the known protein kinase C subspecies (Huang et al., 1987, 1988; Kitano et al., 1987; Mochly-Rosen et al., 1987; Saito et al., 1988), the distribution of protein kinase C of undetermined subspecies (Girard et al., 1985; Wood et al., 1986) or that of total protein kinase $\mathrm{C}$ as determined by biochemical analysis (Walaas et al., 1983a, b) or by autoradiography of phorbol ester binding (Worley et al., 1985). The greatest dissimilarity between the distribution of the MARCKS protein and that of protein kinase $\mathrm{C}$ is found in the hypothalamus, which displays high levels of the MARCKS protein but has low levels of total protein kinase C (Walaas et al., 1983a, b; Worley et al., 1986). The widespread but different distribution of protein kinase $\mathrm{C}$ compared with the MARCKS protein suggests that the 2 proteins are not necessarily highly expressed in the same cells, consistent with the idea that the MARCKS protein subserves only one or a few of the many effects of protein kinase C.

In conclusion, the MARCKS protein is widespread in both neurons and glial cells throughout the rat CNS. The neuronal protein appears enriched in higher-order dendrites, axons, and axon terminals, while the glial protein is present throughout the cytosol. Ultrastructural analysis indicates that the protein may be partly associated with microtubules and that it could be involved in membrane-cytoskeleton interactions. The regional distribution of the protein is indicative of enrichment in neuronal systems that are subject to plastic changes. It will be interesting to anlayze the behavior of the MARCKS protein in identified brain cells under conditions where plastic changes are prevalent.
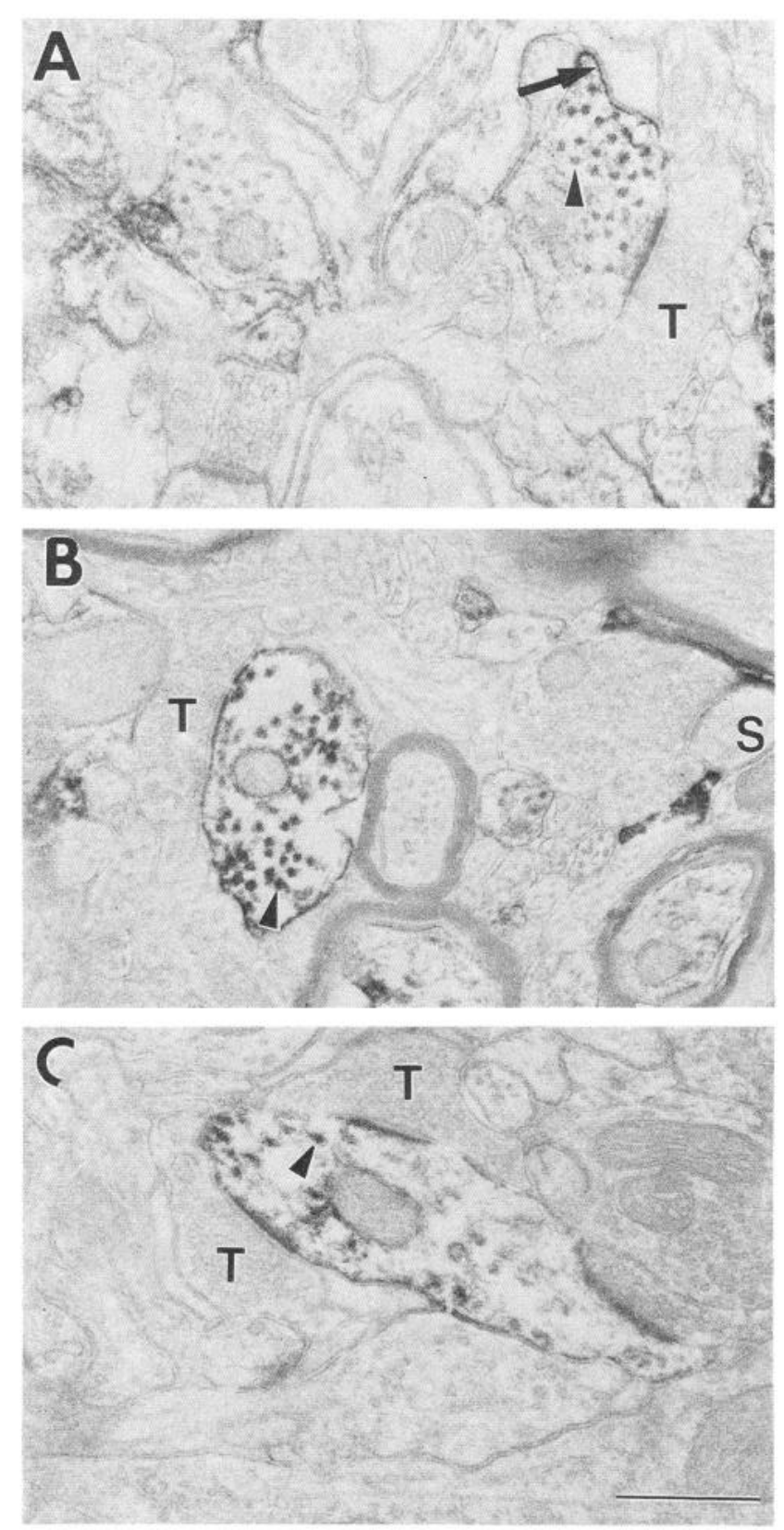

Figure 13. Electron micrograph of immunoreactivity for the MARCKS protein in small dendrites in cingulate cortex $(A, C)$ and hypothalamus $(B)$. Arrowheads point to immunoreactivity associated with dendritic microtubules. Some immunoreactivity is also associated with the inner surface of the dendritic membrane (for example, see arrow in $A$ ). $S$, example of an unlabeled spine; $T$, examples of unlabeled axon terminals. Scale bar, $0.5 \mu \mathrm{m}$.

\section{References}

Aderem AA, Albert KA, Keum MM, Wang JKT, Greengard P, Cohen ZA (1988) Stimulus-dependent myristoylation of a major substrate for protein kinase C. Nature 332:362-364.

Albert KA, Walaas SI, Wang JK-T, Greengard P (1986) Widespread occurrence of " $87 \mathrm{kDa}$," a major specific substrate for protein kinase C. Proc Natl Acad Sci USA 83:2822-2826.

Albert KA, Nairn AC, Greengard P (1987) The $87 \mathrm{kDa}$ protein, a major specific substrate for protein kinase $C$ : purification from bovine brain and characterization. Proc Natl Acad Sci USA 84:7046-7050. Ase K, Saito N, Shearman MS, Kikkawa U, Ono Y, Igarashi K, Tanaka 


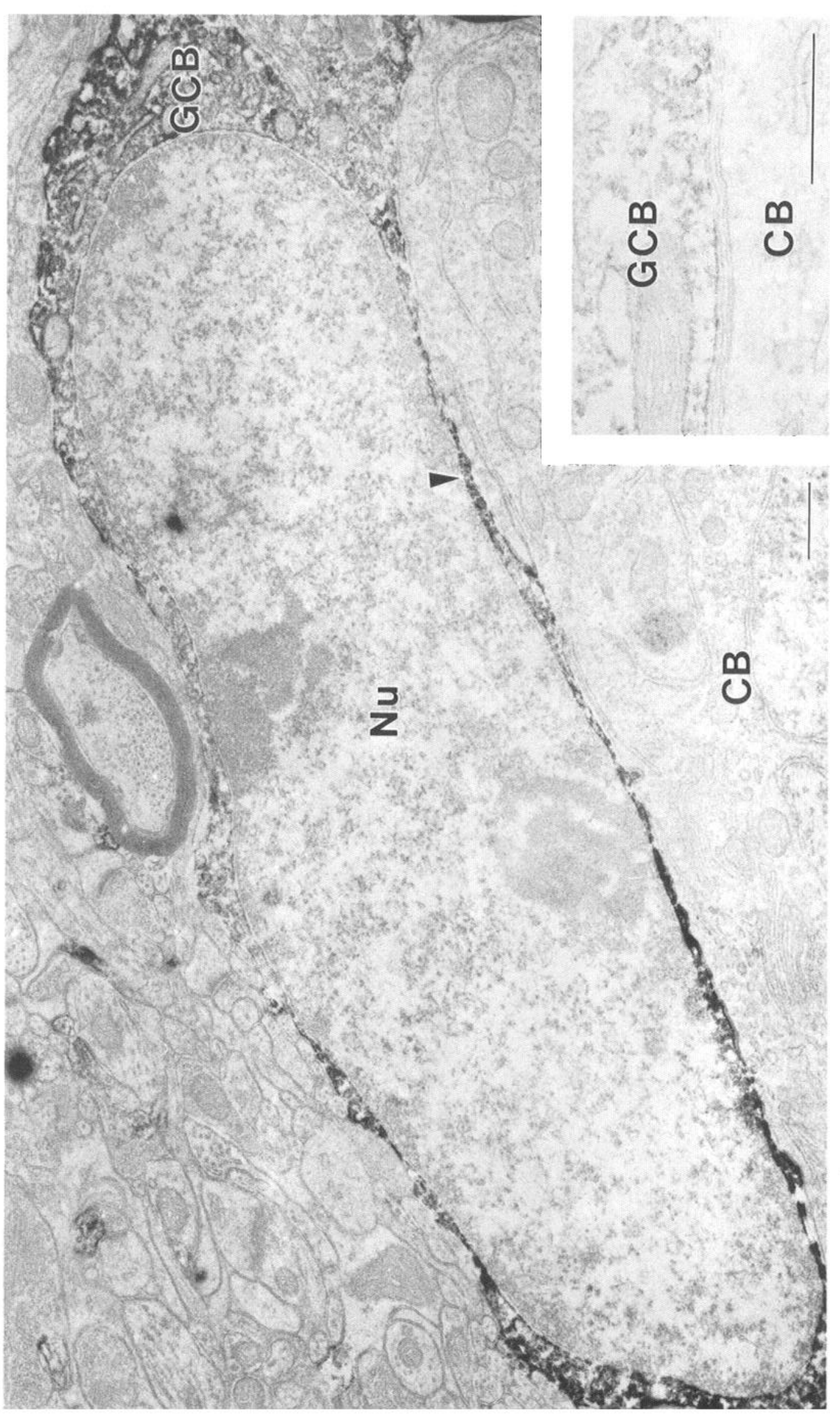

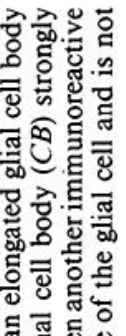

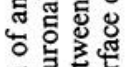

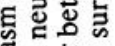

형환.

궁요

농후

웡

둥

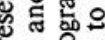

훙응

品

今.

政

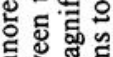

ह

s.

政

泡

은

政

o

a

동

은 $\mathrm{E}$

空

흥 흥

s.

.

s

응 행

在

.

造

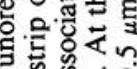

두응

톨

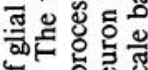

응

s.

啊

은 응

을

政

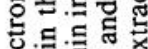

W

4.

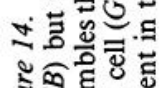

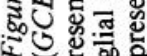



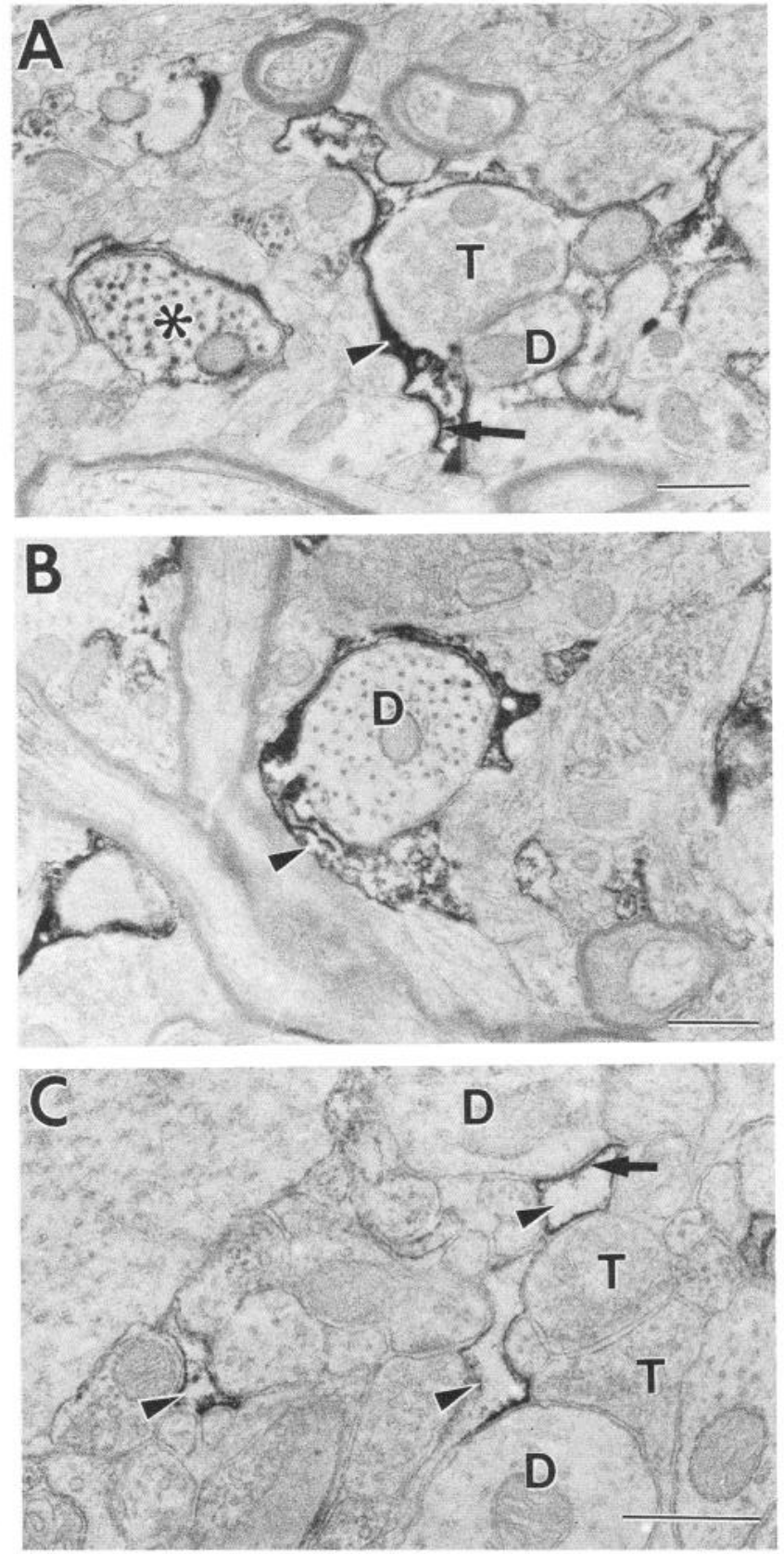

Figure 15. Electron micrographs of immunolabeling for the MARCKS protein in profiles presumed to be glial processes because they often ensheath dendrites and axon terminals. Photomicrographs $A$ and $B$ show immunostaining in the hypothalamus, and $C$ shows immunostaining in region CAl of the hippocampus. $A$, Presumed immunoreactive glial process (arrowhead) associated with an unlabeled axon terminal $(T)$ and unlabeled dendrite $(D)$. Strong immunoreactivity is present on the membrane (arrow). An immunoreactive dendrite (asterisk) is also present. $B$, An unlabeled dendrite $(D)$ is almost surrounded (in the plane of section) by a glia-like immunoreactive process (arrowhead). $C$, Lightly immunoreactive profiles resembling glial processes (arrowheads) associated with unlabeled axon terminals $(T)$ and dendrites $(D)$. In the hippocampus, most of the immunoreaction product in presumed glial processes is associated with the membrane as shown in this photomicrograph. By comparison, more immunoreactivity was cytoplasmic in the presumed glial processes in the hypothalamus. Scale bars, $0.5 \mu \mathrm{m}$.
C, Nishizuka Y (1988) Distinct cellular expression of BI- and BIIsubspecies of protein kinase $C$ in rat cerebellum. J Neurosci 8:38503856 .

Blackshear PJ, Wen L, Glynn BP, Witters LA (1986) Protein kinase C-stimulated phosphorylation in vitro of a $M_{r} 80,000$ protein phosphorylated in response to phorbol esters and growth factors in intact fibroblasts. J Biol Chem 25:1459-1469.

Cammermeyer J (1970) The life history of the microglial cell: a light microscopic study. Neurosci Res 3:43-129.

Coussens L, Parker PJ, Rhee L, Yang-Feng TL, Chen E, Waterfield MD, Franke U, Ullrich A (1986) Multiple, distinct forms of bovine and human protein kinase $\mathrm{C}$ suggest diversity in cellular signaling pathways. Science 233:859-866.

Dunkley PR, Baker CM, Robinson PJ (1986) Depolarization-dependent protein phosphorylation in rat cortical synaptosomes: characterization of active protein kinases by phosphopeptide analysis of substrates. J Neurochem 46:1692-1703.

Girard PR, Mazzei GJ, Wood JG, Kuo JF (1985) Polyclonal antibodies to phospholipid/ $\mathrm{Ca}^{2+}$-dependent protein kinase and immunocytochemical localization of the enzyme in rat brain. Proc Natl Acad Sci USA 82:3030-3034.

Girard PR, Wood JG, Freschi JE, Kuo JF (1988) Immunocytochemical localization of protein kinase $\mathrm{C}$ in developing brain tissue and in primary neuronal cultures. Dev Biol 126:98-107.

Hashimoto TK, Ase K, Sawamura S, Kikkawa U, Saito N, Tanaka C, Nishizuka Y (1988) Postnatal development of a brian-specific subspecies of protein kinase $C$ in rat. J Neurosci 8:1678-1683.

Housey GM, O'Brian CA, Johnson MD, Kirschmeier P, Weinstein IB (1987) Isolation of cDNA clones encoding protein kinase C: evidence for a protein kinase C-related gene family. Proc Natl Acad Sci USA 84:1065-1069.

Huang FL, Yoshida Y, Nakabayashi H, Huang K-P (1987) Differential distribution of protein kinase $\mathrm{C}$ isozymes in the various regions of brain. J Biol Chem 262:15714-15720.

Huang FL, Yoshida Y, Nakabayashi H, Young WS, III, Huang K-P (1988) Immunocytochemical localization of protein kinase $\mathrm{C}$ isozymes in rat brain. J Neurosci 8:4734-4744.

Hyman C, Pfenninger KH (1987) Intracellular regulators of neuronal sprouting: II. Phosphorylation reactions in isolated growth cones. J Neurosci 7:4076-4083.

Kaczmarek L (1987) The role of protein kinase C in the regulation of ion channels and neurotransmitter release. TINS 10:30-34.

Katz F, Ellis L, Pfenninger KH (1985) Nerve growth cones isolated from fetal rat brain. III. Calcium-dependent protein phosphorylation. J Neurosci 5:1402-1411.

Kikkawa U, Nishizuka Y (1988) The role of protein kinase C in transmembrane signalling. Annu Rev Cell Biol 2:149-178.

Kitano T, Hashimoto T, Kikkawa U, Ase K, Saito N, Tanaka C, Ichimori Y, Tsukamoto K, Nishizuka Y (1987) Monoclonal antibodies against rat brain protein kinase $\mathrm{C}$ and their application to immunocytochemistry in nervous tissues. J Neurosci 7:1520-1525.

Knopf JL, Lee M-H, Sultzman LA, Krig RW, Loomis CR, Hewick RM, Bell RM (1986) Cloning and expression of multiple protein kinase C cDNAs. Cell 46:491-502.

Kubo K, Ohno S, Suzuki K (1987) Primary structure of human protein kinase $\mathrm{C}$ bI and bII differ only in their C-terminal sequences. FEBS Lett 223:138-142.

Lichtensteiger W, Richards JG (1975) Tuberal DA neurons and tanycytes: response to electrical stimulation and nicotine. Experientia 31: 742.

Makowske MM, Birnbaum J, Ballester R, Rosen OM (1986) A cDNA encoding protein kinase $C$ identifies two species of mRNA in brain and $\mathrm{GH}_{3}$ cells. J Biol Chem 261:13389-13392.

Meister B, Hökfelt T, Tsuruo Y, Hemmings H, Ouimet C, Greengard P, Goldstein M (1988) DARPP-32, a dopamine- and cyclic AMPregulated phosphoprotein in tanycytes of the mediobasal hypothalamus: distribution and relation to dopamine and luteinizing hormonereleasing hormone neurons and other glial elements. Neuroscience 27:607-622.

Miles JM, Chou SM (1988) A new immunoperoxidase marker for microglia in paraffin section. J Neuropathol Exp Neurol 47:579-587.

Mochly-Rosen D, Basbaum AI, Koshland DE, Jr (1987) Distinct cellular and regional localization of immunoreactive protein kinase $\mathrm{C}$ in rat brain. Proc Natl Acad Sci USA 84:4660-4664.

Nelson RB, Friedman DP, O'Neill JB, Mishkin M, Routtenberg A 
(1987) Gradients of protein kinase C substrate phosphorylation in primate visual system peak in visual memory storage areas. Brain Res 416:387-392.

Nishizuka Y (1986) Studies and perspectives of protein kinase C. Science 233:305-312.

Nishizuka Y (1988) The molecular heterogeneity of protein kinase C and its implications for cellular regulation. Nature 344:661-665.

Olmsted JB (1981) Affinity purification of antibodies from diazotized paper blots of heterogeneous protein samples. J Biol Chem 256:1 195511957.

Ohno S, Kawasaki H, Imajoh S, Suzuki K, Inagaki M, Yokokura H, Sakoh T, Hidaka H (1987) Tissuc-specific expression of three distinct types of rabbit protein kinase C. Nature 325:161-166.

Ono Y, Kurokawa T, Kawahara K, Nishimura O, Marumoto R, Igarashi K, Sugino Y, Kikkawa U, Ogita K, Nishizuka Y (1986a) Cloning of rat brain protein kinase C complementary DNA. FEBS Lett 203: $111-115$.

Ono Y, Kurokawa T, Fujii T, Kawahara K, Igarashi K, Kikkawa U, Ogita K, Nishizuka Y (1986b) Two types of complementary DNAs of rat brain protein kinase $\mathrm{C}$. Heterogeneity determined by alternative splicing. FEBS Lett 206:347-352.

Parker PJ, Coussens L, Totty N, Rhee L, Young S, Chen E, Stabel S, Waterfield MD, Ullrich A (1986) The complete primary structure of protein kinase $\mathrm{C}$-the major phorbol ester receptor. Science 233: 853-859.

Patcl J, Kligman D (1987) Purification and characterization of an $M_{r} 87,000$ protein kinase $\mathrm{C}$ substrate from rat brain. J Biol Chem 34 16686-16691.

Rio-Hortega P del (1932) Microglia. In: Cytology and cellular pathology of the nervous system (Penfield W, ed), pp 481-584. New York: Hocker.

Rozengurt E, Rodriguez-Pena M, Smith KA (1983) Phorbol esters, phospholipase $\mathrm{C}$, and growth factors rapidly stimulate the phosphorylation of a $\mathrm{M}_{\mathrm{r}} 80,000$ protein in intact quiescent 3T3 cells. Proc Natl Acad Sci USA 80:7244-7248.

Saito N, Kikkawa U, Nishizuka Y, Tanaka C (1988) Distribution of protein kinase $\mathrm{C}$-like immunoreactive neurons in rat brain. J Neurosci 8:369-382.

Smith PK, Krohn RI, Hermanson GT, Mallia AK, Gartner FH, Provenzano MD, Fujimoto EK, Goeke NM, Olson BJ, Klenk DC (1985) Measurement of protein using bicinchoninic acid. Anal Biochem 150: $76-85$.

Stumpo DJ, Graff JM, Albert KA, Greengard P, Blackshear PJ (1989) Molecular cloning, characterization, and expression of a cDNA encoding the (80- to $87-\mathrm{kDa}$ ) myristoylated alanine-rich $\mathrm{C}$ kinase substrate: a major cellular substrate for protein kinase C. Proc Natl Acad Sci USA 86:4012-4016.

Tweedle CD, Hatton GI (1987) Morphological adaptability at neurosecretory axonal endings on the neurovascular contact zone of the rat neurohypophysis. Neuroscience 20:241-246.

Walaas SI, Nairn AC, Greengard P (1983a) Regional distribution of calcium-and cyclic AMP-regulated protein phosphorylation systems in mammalian brain. I. Particulate systems. J Neurosci 3:291-301.

Walaas SI, Nairn AC, Greengard P (1983b) Regional distribution of calcium- and cyclic AMP-regulated protein phosphorylation systems in mammalian brain. II. Soluble systems. J Neurosci 3:302-311.

Wang JKT, Walaas SI, Greengard P (1988) Protein phosphorylation in nerve terminals: comparison of calcium/calmodulin-dependent and calcium/diacylglycerol-dependent systems. J Neurosci 8:281-288.

Wang JKT, Walaas SI, Sihra T, Aderem A, Greengard P (1989) Phosphorylation and associated translocation of the $87-\mathrm{kDa}$ protein, a major protein kinase $C$ substrate, in isolated nerve terminals. Proc Natl Acad Sci USA 86:2253-2256.

Wood JG, Girard PR, Mazzei GJ, Kuo JF (1986) Immunocytochemical localization of protein kinase $\mathrm{C}$ in identified neuronal compartments of rat brain. J Neurosci 6:2571-2577.

Worley PF, Baraban JM, Snyder SH (1986) Heterogeneous localization of protein kinase $\mathrm{C}$ in rat brain: autoradiographic analysis of phorbol ester receptor binding. J Neurosci 6:199-207.

Wu WC-S, Walaas SI, Nairn AC, Greengard P (1982) Calcium/phospholipid regulates phosphorylation of a $M_{r}$ " $87 \mathrm{k}$ " substrate protein in brain synaptosomes. Proc Natl Acad Sci USA 79:5249-5253. 